\title{
PTARMIGAN IN NORTH AMERICA: INFLUENCE OF LIFE HISTORY AND ENVIRONMENTAL CONDITIONS ON POPULATION PERSISTENCE
}

\author{
Kathy MARTIN ${ }^{1,2}$ AND SCOTT WILSON ${ }^{3}$ \\ ${ }^{1}$ Department of Forest Sciences, University of British Columbia, 2424 Main Mall, \\ Vancouver, British Columbia V6T1Z4, Canada. \\ E-mail: kathy.martin@ubc.ca
}

${ }^{2}$ Environment Canada, 5421 Robertson Road, Delta, British Columbia V4K 3N2, Canada

${ }^{3}$ Canadian Wildlife Service, Environment Canada, 115 Perimeter Road, Saskatoon, Saskatchewan S7N OX4, Canada

\begin{abstract}
Three ptarmigan species (Willow Ptarmigan Lagopus lagopus, Rock Ptarmigan L. muta, and White-tailed Ptarmigan L. leucura) occupy the tundra habitats of North America. Willow and Rock Ptarmigan inhabit arctic and alpine regions of Canada and Alaska, while Whitetailed Ptarmigan occupy alpine habitats from Alaska and northern Canada south to New Mexico. Ptarmigan populations have relatively short generation times (1.7 to 2.62 years) with an annual fecundity of 0.4 to 2.04 female fledglings/female. In some populations, annual fecundity depends strongly on re-nesting to replace failed first clutches (predation rate usually $>50 \%$ ). We use demographic data from five study sites (38 study-years) to demonstrate that the life history of the North American ptarmigan varies from fast ( $\mathrm{r}$-selection/high fecundity) to slow life styles (Kselection/high survival). Willow Ptarmigan, living in sub-arctic and sub-alpine habitats, have a fast life history. Their populations are most strongly influenced by fecundity and survival of juveniles and yearling females. At the other end of the spectrum, Rock Ptarmigan have a slower life history with nearly $40 \%$ lower reproductive output, but over $20 \%$ higher adult survival rate. Interestingly, White-tailed Ptarmigan show within-species variation from fast to slow lifestyles across their latitudinal range. White-tailed Ptarmigan in the Yukon allocate more effort to reproduction than those in Colorado, but they have lower annual survival, suggesting that environmental factors can lead to life history shifts even within species. In all species, a well-developed external recruitment (rescue) capacity allows ptarmigan populations to persist in stochastic conditions for breeding and survival. The impact of climate change is expected to differ with life history. Slow life style ptarmigan populations are buffered more from climate change influences that impact fecundity but they are more vulnerable to environmental processes that decrease adult survival than the fast life style Willow Ptarmigan. Received 22 June 2011, accepted 27 September 2011.
\end{abstract}

Martin, K., AND S. WiLSON. 2011. Ptarmigan in North America: Influence of life history and environmental conditions on population persistence. Pages 45-54 in R. T. Watson, T. J. Cade, M. Fuller, G. Hunt, and E. Potapov (Eds.). Gyrfalcons and Ptarmigan in a Changing World, Volume I. The Peregrine Fund, Boise, Idaho, USA. http://dx.doi.org/10.4080/gpcw.2011.0105 
Key words: Climate change, ecology, North America, demographic model, vital rates, Rock Ptarmigan, Willow Ptarmigan, White-tailed Ptarmigan.

IN THIS OVERVIEW OF PTARMIGAN in North America, we focus on their population ecology, life history traits, and responses to environmental variation, particularly climate change. All three species of Lagopus occur in North America: the White-tailed Ptarmigan (Lagopus leucura), which is largely an alpine bird in the western part of the continent (Braun et al. 1993), the Rock Ptarmigan (L. muta), a high arctic and alpine species (Holder and Montgomerie 2008), and the Willow Ptarmigan (Lagopus lagopus), a sub-arctic and subalpine species in northern Canada (Hannon et al. 1998). Ptarmigan are distributed in North America from eastern Newfoundland to the western Aleutian Islands, and from the high arctic islands south to New Mexico, covering a considerable span of latitude, maybe 5,000 $\mathrm{km}$, and over 4,000 km of longitude (Figure 1). The total distribution of ptarmigan in all seasons covers over half the landmass of Canada.

All ptarmigan species are distinguished among the grouse as being monogamous, inhabiting tundra environments, and displaying seasonally variable camouflage by molting between a brown summer plumage and a white winter plumage. They are precocial birds, with a three week incubation period, and typically produce only one brood per year, although they may renest up to four times following nest failure (Wiebe and Martin 1998, Martin et al. 2011). Most North American populations exhibit unstable dynamics. In more northerly regions, populations tend to fluctuate on a $\sim 10$ year cycle (Johnsgard 1983, Bergerud and Gratson 1988, p 656). Only some southern populations show cyclic dynamics, while others display less regular fluctuations in population abundance patterns.

About 10 multi-year population studies have been done on ptarmigan in North America (Figure 1). In a few areas in northwestern North America, the three species of ptarmigan occur and breed sympatrically. For example, in our southern Yukon study site we have Whitetailed Ptarmigan on rocky slopes at the highest elevations, Rock Ptarmigan in lower alpine meadows with some overlap with White-tailed Ptarmigan depending on the habitat configuration, and Willow Ptarmigan at the lowest elevations in shrubby, subalpine habitats (Wilson and Martin 2008). It is unusual to have congeneric species with similar ecologies breeding sympatrically.

For ptarmigan populations in North America, it is feasible to capture most birds at the beginning of the breeding season, making it possible to mark most of the population with color bands or telemetry, and follow many of the key vital rates for populations through the season from clutch initiation, clutch size, and nest survival to hatching success of chicks and the survival and return of adults and juveniles in subsequent years. Thus, researchers are able to obtain quantitative measures of vital rates to determine the most important factors in determining population change (Sandercock 2006, Saether and Bakke 2000).

Ptarmigan life history appears to be driven primarily by predation rates of different age classes (Martin 1985, Hik et al. 1986, Sandercock et al. 2005 a, b, Wilson and Martin 2011), but weather is also important (Hannon et al. 1988, Wilson and Martin 2010). Tundra environments are characterized by severe weather, such as late spring snow storms after first eggs are laid. These events can lead to a negative synergism between late snowfall and increased predation in some years (Martin and Wiebe 2004, Wilson 2008, Wang et al. 2002). Ptarmigan, especially White-tailed and Willow Ptarmigan, will re-nest if the first clutch is lost before the end of incubation and the re-nests are often more successful than the first clutch (Martin et al. 1989, Martin et al. 2011, Wilson et al. 2007). Overall, ptarmigan populations 
have relatively short generation times (1.7 to 2.62 years) with an annual fecundity of 0.4 to 2.04 female fledglings/female (Sandercock et al. 2005 b, Wilson and Martin 2011).

\section{Ptarmigan Distribution, Population Dynamics, ANd Life History Variation}

Willow Ptarmigan.-Willow Ptarmigan occur across North America from eastern Newfoundland west to Alaska and the Aleutian Islands (Hannon et al. 1998). There have been several multi-year population studies, including $\mathrm{K}$. Martin's Ph.D. study on Willow Ptarmigan near Churchill, Manitoba in sub-arctic tundra (Martin 1984, Martin and Cooke 1987, Martin et al. 1989), and two studies conducted in subalpine habitat in the Chilkat Pass, Northwestern British Columbia, Canada, one by S. Hannon for 15 years (Hannon et al. 1988, 1998), and a second, longer, population survey study by D. Mossop (Mossop 2011). Studies of Willow Ptarmigan were also conducted in Newfoundland, the eastern extent of the species range (Bergerud and Huxter 1969, Bergerud and Gratson 1988, Mercer 1967).

These population studies of Willow Ptarmigan show that almost all females attempt to breed every year. With re-nesting after failure of previous nesting attempts, from $50 \%$ to $75 \%$ of them produce at least one chick. If the chicks leave the nest, generally $60 \%$ to $70 \%$ survive to independence ( $\sim 60$ days). Of these, some are depredated by raptors on migration, leaving about half of them to survive and enter the breeding population for the first time the next year. These demographic data can be used to create a population matrix model for Willow Ptarmigan that begins with independent juveniles surviving their first winter to enter the breeding population $\left(\mathrm{S}_{0}\right.$, Figure 2$)$. As yearling birds or first time breeders, these first year birds have a certain probability of producing young (fecundity, $\mathrm{F}_{1}$ ), and surviving to become two-year-olds $\left(\mathrm{S}_{1}\right)$. The same calculations can be done for two-year-olds $\left(\mathrm{S}_{2}, \mathrm{~F}_{2}\right)$ and threeyear-olds $\left(\mathrm{S}_{3}, \mathrm{~F}_{3}\right)$. The resultant matrix model

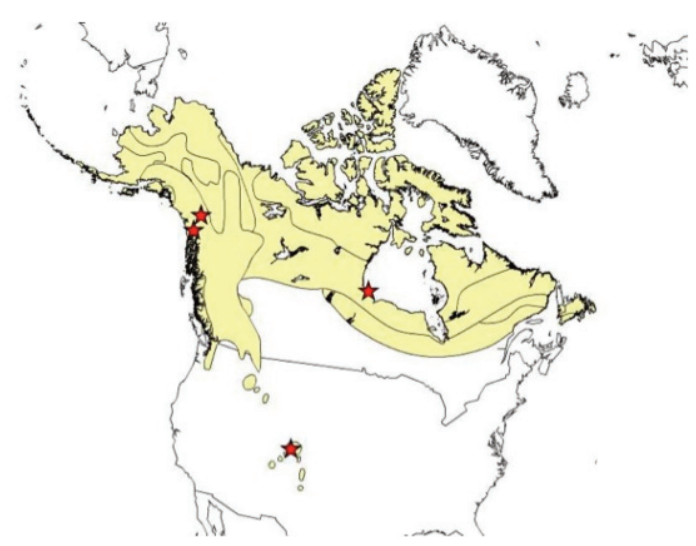

Figure 1. The distribution of arctic and alpine ptarmigan in North America (shaded area). Stars indicate locations of authors' multi-year ptarmigan population studies.

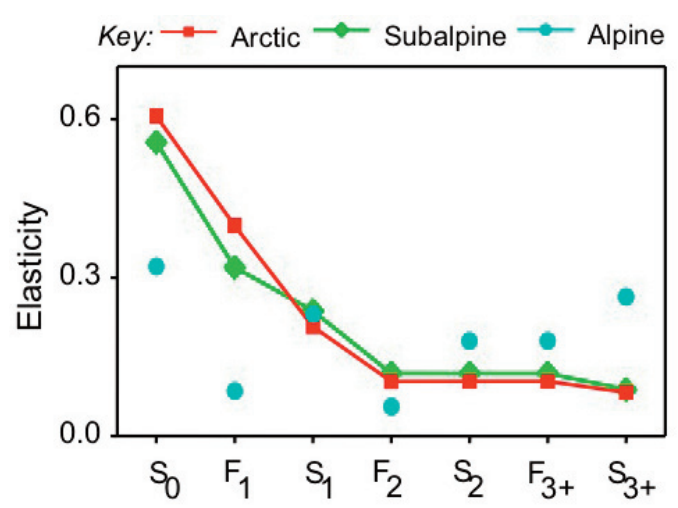

Age-specific Survival (S) \& Fecundity (F)

Figure 2. An elasticity analysis of age-structured survival and fecundity vital rates for two populations of Willow Ptarmigan inhabiting subarctic (red-line, Churchill, Manitoba, K. Martin data) or subalpine tundra (green line, Chilkat Pass, British Columbia, S. J. Hannon data) shows that future population growth will be most strongly influenced by juvenile survival $\left(S_{0}\right.$, elasticity value of $\sim 0.6$ for both populations), secondly by fecundity of yearling females $\left(F_{1}\right)$ and thirdly by survival of yearling females (Sf). Vital rates at later life history stages are predicted to have relatively less influence than survival or fecundity of younger birds. Adapted after data in Sandercock et al. (2005b). 


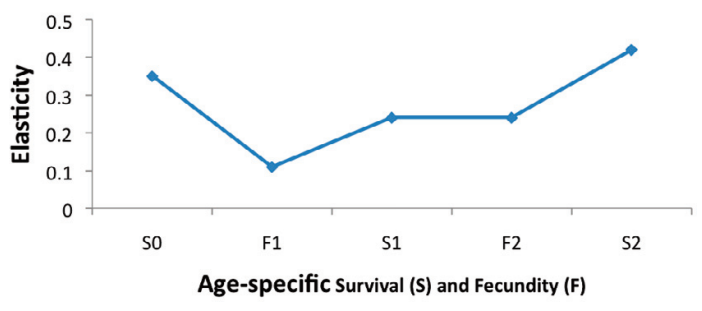

Figure 3. An elasticity analysis of age-structured survival and fecundity vital rates for a population of Rock Ptarmigan inhabiting northern alpine tundra in the southwestern Yukon (Wilson 2008) shows that future population growth will be most strongly influenced by survival of older birds $\left(S_{2}\right.$, elasticity value of $\sim 0.4$ ), and secondly by survival of juveniles $\left(S_{0}\right)$. Thus vital rates related to survival are predicted to have stronger influence than fecundity vital rates (Wilson 2008, and Wilson and Martin, unpublished data).

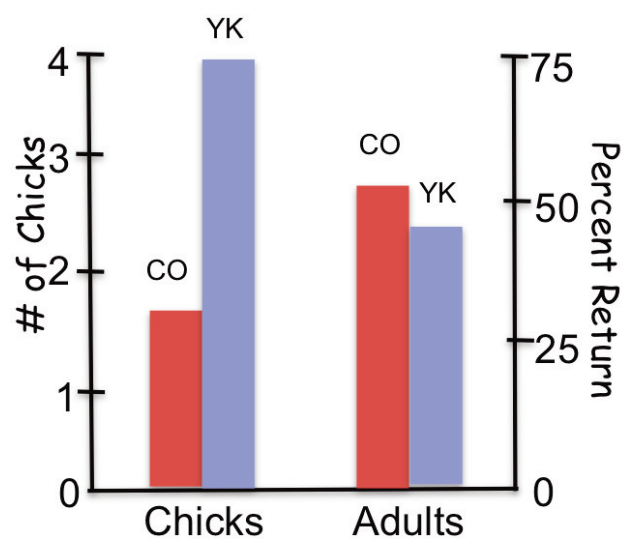

Figure 4. Variation in fecundity (number of chicks produced) and return of adult birds in the following year in two White-tailed Ptarmigan populations at the altitudinal range limits $(\mathrm{CO}=$ Colorado (red), YK= Yukon (blue), adapted from Wilson and Martin, 2011). generates a fecundity and survival matrix for different age classes of individuals (Figure 2). From this, Sandercock et al. (2005b) calculated an elasticity measure (which is the change predicted in the population growth rate from a proportional change in a vital rate) for our populations of Willow Ptarmigan in Churchill, Manitoba and in British Columbia to reveal which vital rate is the most influential. By far the most important vital rate in predicting future population growth for both populations was the survival of juveniles from fledging to the following breeding season. The second most important variable was the fecundity of yearling birds (Sandercock et al. 2005b). This means that Willow Ptarmigan in much of their range, likely including both Europe and North America, have a fast life history that is characterized by high fecundity (1.33-2.04 female young/hen), relatively low annual adult survival (37-43\%), and short generation times (Sandercock et al. 2005 a,b, Hannon and Martin 2006, Hannon et al. 1998).

Rock Ptarmigan.-Rock Ptarmigan occur across North America from western Newfoundland west to Alaska and the outer Aleutian Islands and north to the high arctic islands (Holder and Montgomerie 2008). There have been few multi-year population studies, aside from MacDonald's classic behavior study on Ellesmere Island, and shorter-term studies at Sarcpa Lake in the Northwest Territories (MacDonald 1970, Holder and Montgomerie 2008), and a recent 5-year study in the southwestern Yukon, Canada (Wilson 2008, Wilson and Martin 2010). Some monitoring studies of Rock Ptarmigan have been conducted in western Newfoundland and Labrador (Peters and Burleigh 1951).

In contrast to Willow Ptarmigan, Rock Ptarmigan demographic data from a 5-year study in the southwest Yukon reveal much more balance in the vital rates that are most influential in predicting future population change (Figure 3). The highest elasticity values were those for the survival of juveniles (about 0.4) and survival of 
older adult females (Wilson 2008). Thus, the main factor influencing Rock Ptarmigan population change appears to be survival; both survival of independent juveniles, and survival of older birds. Their life history is significantly slower, with relatively low reproductive output but high adult survival (about 70\%, Wilson and Martin 2010). Rock Ptarmigan, in general, appear to have a slower life-style as a number of other studies, for example in the French Pyrenees (Novoa et al. 2011) and Japan (Nakamura, pers. comm.), have found the species follows a low annual fecundity but high survivorship strategy.

White-tailed Ptarmigan.-The White-tailed Ptarmigan has a distribution restricted to western North America but the latitudinal range extends about $30^{\circ}$ from southern Alaska and the Yukon in the north to northern New Mexico in the south. Comparisons were conducted on the life history and ecology of the species at latitudinal extremes of the range as we studied populations in the southwest Yukon, and at the southern extent of its range in Colorado (where C.E. Braun and others have monitored populations for c. 45 years, Braun et al. 1993, Sandercock et al. 2005a, Oyler-McCance et al. 2011). These two sites are separated by about $2,400 \mathrm{~km}$ of latitude, and a distance of about $3,200 \mathrm{~km}$. In the Yukon we found that birds had a significantly smaller body size $(11 \%$ smaller) than birds in Colorado, but the clutch sizes were $20 \%$ larger with, on average, 2.2 more eggs per clutch (Wilson and Martin 2011). These eggs were $8 \%$ smaller, yet their hatchability was $10 \%$ higher in the Yukon. When we compared fecundity and adult survival between the two populations, we found that White-tailed Ptarmigan in the Yukon produced, on average, about twice as many chicks (c. 4 chicks) in the breeding season compared to Colorado (c. 2 chicks, Figure 4). However, the Colorado adult birds had a 9\% higher survival rate. Using the elasticity measure to compare the demographic rates of these two populations, we found that the most important vital rate predicting population change of the Yukon birds was the survival of juveniles,

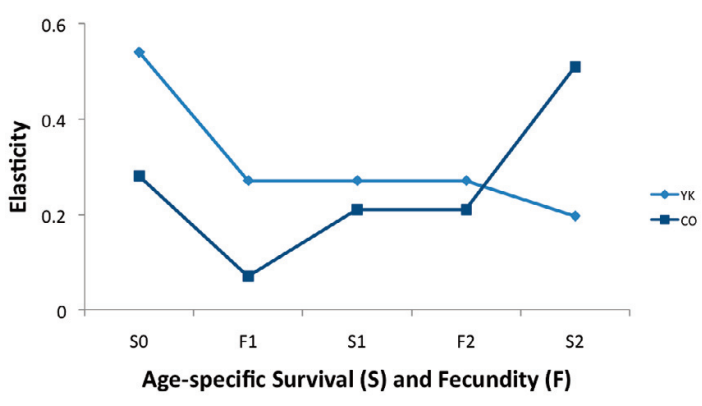

Figure 5. Life history variation for two populations of White-tailed Ptarmigan at their altitudinal range limits: elasticity measures indicate that survival of juveniles $\left(\mathrm{S}_{0}\right)$ predicts future population growth in ptarmigan in the Yukon (YK), while survival of older birds $\left(S_{2}\right)$ has the strongest influence on population growth for the species in Colorado (CO) (adapted from Wilson and Martin, 2011).

comparable to the Willow Ptarmigan (Figure 5, Wilson and Martin 2011). The most important vital rate for the same species in Colorado, however, was the survival of older females. Thus, White-tailed Ptarmigan exhibit dramatic life history variation within the species that is fast in the north and slow in the south.

Collectively, we see impressive variation in life history within the five populations (three species) of ptarmigan that have been examined in detail. Willow Ptarmigan, and the Whitetailed Ptarmigan in the Yukon, have a relatively fast, short life that is driven by variation in annual fecundity. Rock Ptarmigan, and the White-tailed Ptarmigan in Colorado, have a relatively slow, long life with annual survival as the more important vital rate.

Dispersal movements between suitable patches are critical for maintaining populations, particularly alpine populations that occur in patches of suitable habitat situated in an otherwise unsuitable landscape. Because demographic rescue is an important feature for the persistence of alpine ptarmigan, the loss of connectivity between populations increases the probability of local extinction (Martin et al. 2000). Using both radio telemetry and genetic 
micro-satellite markers, we studied demographic and genetic connectivity in Whitetailed Ptarmigan among seven population clusters across patchy alpine habitats on Vancouver Island (Canada). We found there was significant genetic connectivity across all these patches, with the exception of the southernmost population cluster where there was reduced connectivity. Among six of the seven population clusters there was evidence of movement of alleles and therefore individuals across the landscape. Overall, the sub-species of White-tailed Ptarmigan endemic to Vancouver Island showed very little genetic structure and appear to be a single population (Martin et al. 2004, Fedy et al. 2008). This study has important implications given that climate change is predicted to increase the degree of habitat fragmentation, and populations are anticipated to become more isolated in this coastal alpine habitat.

\section{Climate Change}

One of the characteristics of high latitude and high elevation environments is the degree of climate warming has been significantly greater than the rest of the world, about $+2-3^{\circ} \mathrm{C}$ versus the global mean of $0.6^{\circ} \mathrm{C}$ over the past 100 years (IPCC 2007). What may pose the biggest immediate problem are changes in the type of precipitation from reliable snowfall to lethal mixtures of ice and rain, which lowers survival for many animals including ptarmigan. Ptarmigan are strongly associated with snow for most of the year, and in summer they rely on persistent snow fields for crypticity, cooling, and to provide a continuous supply of new vegetative growth at the edge of snow fields (Martin 2001). In winter, habitat needs for ptarmigan include a reliable supply of winter snow and shrub habitat for foraging. With the exception of migratory northern populations, winter habitats are typically near breeding sites but often in locations with greater shrub cover.

Climate change is associated with an increase in environmental variability that may have a number of potential effects on ptarmigan, even though they are generally well adapted to deal with significant levels of climate stochasticity. Climatic variability results in increased seasonal variation in timing of snow melt that impacts timing of breeding. When conditions are snow free early (early May vs the norm of early June) initiation of breeding can start earlier if birds track spring conditions, as Willow Ptarmigan tend to do (Hannon et al. 1988). However, in recent years, we have observed extreme delays in snow melt $(100 \%$ snow cover in mid-June or up to one meter of snow in late June), and under these conditions, birds are unable to initiate breeding as they require snow-free ground to place their nests. Thus, alpine breeding ptarmigan must be flexible enough to delay breeding by up to a month, and with increasing climatic variability, alpine tundra habitats will become increasingly unreliable habitats (Martin 2001, Martin and Wiebe 2004). Late years usually result in lower annual fecundity for ptarmigan (Martin et al. 2000), and warmer winters with low snow cover are expected to have a negative impact on over-winter survival of adult ptarmigan (Wang et al. 2002a, b).

In terms of the implications of climate variability on ptarmigan population dynamics, we have observed very different responses to unfavorable weather by two ptarmigan species breeding sympatrically in the Yukon. Under harsher weather conditions, Rock Ptarmigan delay breeding and will forego re-nesting. This may be a strategy to avoid the risks of breeding under difficult conditions, given their higher probability of survival and thus greater likelihood of breeding opportunities in the following season (Wilson and Martin 2010). In contrast, Willow Ptarmigan and White-tailed Ptarmigan in the Yukon have lower annual survival and a strategy that is geared towards greater reproductive effort in the current season. Thus it appears that responses to unfavorable environmental conditions associated with climate change vary among ptarmigan and are correlated with their different life-history strategies. 
In terms of fine-grained responses to environmental variability, incubating ptarmigan can respond behaviorally to climate variation to some extent. For example, birds nesting in more exposed situations, such as on bare ground where temperatures can reach 40$50^{\circ} \mathrm{C}$, adjust the timing of their incubation recesses so they leave the nest earlier or later in the day when it is cooler and remain on the nest to shade and cool the eggs during the hottest part of the day (Wiebe and Martin 2000). Their flexibility to respond behaviorally to changing thermal regimes such that they can maintain eggs and young at suitable temperatures for optimal development may enable ptarmigan to adjust to some of the increased environmental variability they will experience in their tundra habitats in the coming decades.

Rising tree and shrub lines in mountain habitats will result in more sub-alpine habitat and less alpine habitat in smaller patches. In this scenario Willow Ptarmigan habitat is predicted to increase, Rock Ptarmigan habitat is likely to rise to higher elevations and possibly higher latitudes, and White-tailed Ptarmigan may end up in smaller, more fragmented patches, and their ability to disperse between patches will become more important for their persistence. It is difficult to predict precise outcomes for high elevation ptarmigan given the complexity in aspect and elevation and micro-climatic variability in mountain habitats. In ptarmigan habitats in the Yukon, most of the nests are on south-facing slopes where there is earlier snow melt (Wilson and Martin 2008). As climates warm, shrub-lines are expected to rise, and south-facing slopes may eventually be covered with willow. However, conditions on the north-facing slopes might ameliorate such that they have earlier snow melt and conditions that become suitable for ptarmigan. Thus, complexity in elevation and aspect may allow ptarmigan to persist under climate warming given their flexibility in breeding behavior and phenology, and spatial use of the landscape.
At the continental scale, the first implication of climate change is that its impact differs among closely related species (Wilson and Martin 2010). Impacts that reduce fecundity are predicted to be relatively more influential on fast lifestyle ptarmigan populations like the Willow Ptarmigan, whereas impacts like a rain-ice event in winter that increase mortality of older females will likely have a bigger effect on populations that show a slow lifestyle dependent on adult survival.

\section{Status of Ptarmigan Populations IN NORTH AMERICA}

Globally, ptarmigan still occupy most of their original ranges, and they are considered to be the best-protected grouse species because of their often remote habitats, but there are emerging concerns that some populations are declining (Johnsgard 1983, Storch 2000, 2007, Sandercock et al. 2011). It is extremely challenging to determine populations at risk and summarize population status for North American ptarmigan when so few populations have been studied or monitored over a continental landmass that stretches from Newfoundland to the Aleutian Islands and from Ellesmere Island south to New Mexico (Figure 1). The major threats to population viability of ptarmigan in North America vary regionally and include exploitation (hunting), predation (specifically introduced predators), human disturbance (usually local, such as mining or cattle grazing) and climate change (Johnsgard 1983, Braun et al. 1993, Hannon et al. 1998, Holder and Montgomerie 2008).

Most of the populations identified as at risk or in decline are on the periphery of the North American continent. Newfoundland supports two ptarmigan species, both with sub-species endemic to the island. In eastern Newfoundland, Willow Ptarmigan (L. l. alleni) populations have declined sharply in the Avalon Peninsula, possibly due to over-hunting given 
the fact that the birds do not migrate far from their breeding areas and there is easy access by hunters to their winter areas. However, despite considerably less hunting pressure in western Newfoundland, both Willow Ptarmigan and Rock Ptarmigan populations occur at very low densities throughout the island of Newfoundland. Since ptarmigan in Newfoundland occur at the lowest latitudes for these two northern breeding birds, the birds may be challenged by the recent increases in environmental variability due to climate change.

In the extreme northwest of North America, Evermann's Rock Ptarmigan, (L. $m$. evermanni) endemic to the Near Islands of the Western Aleutian Archipelago of Alaska, was extirpated from all but one island (Attu) due to predation after the introduction of nonnative Arctic Foxes (Vulpes lagopus) (Kaler and Sandercock 2011). Several small groups of Evermann's Rock Ptarmigan were translocated from Attu Island to nearby islands where foxes were removed. The ptarmigan succeeded in establishing for the first few years after release.

One subspecies of White-tailed Ptarmigan endemic on Vancouver Island (L. leucura saxatilis) is blue-listed in British Columbia because of low and stochastic population abundance (Martin et al. 2004). In New Mexico, the very southern edge of White-tailed Ptarmigan range, the climate is warming and drying in summer, to make for hotter and drier conditions in these southern alpine habitats that will challenge further the already small ptarmigan populations (IPCC 2007). In general, it is likely that most populations of all three ptarmigan species will continue to persist over much of their current distribution, as they occur in habitats that remain in relatively natural conditions and where human populations are at low density. However, at the periphery of the distribution for each species, there are endemic sub-species that have or soon will be experiencing serious population declines.

\section{Literature Cited}

Bergerud, A. T., AND D. S. HuXter. 1969. Breeding season habitat utilization and movement of Newfoundland Willow Ptarmigan. Journal of Wildlife Management 33:967-974.

Bergerud, A. T., AND M. W. Gratson. 1988. Adaptive strategies and population ecology of northern grouse. University of Minnesota Press, Minneapolis, Minnesota, USA.

Braun, C. E., K. Martin, and L. A. Robb. 1993. White-tailed Ptarmigan (Lagopus leucurus). In A. Poole, P. Stettenheim, and F. Gill (Eds.). The Birds of North America, no. 68. Academy of Natural Sciences, Philadelphia, and American Ornithologists' Union, Washington, DC, USA.

Fedy, B. C., K. Martin, C. Ritland, And J. Young. 2008. Genetic and ecological data provide incongruent interpretations of population structure and dispersal in naturally subdivided populations of White-tailed Ptarmigan (Lagopus leucura). Molecular Ecology 17:1905-1917.

HANNON, S. J., AND K. MARTIN. 2006. Ecology of juvenile grouse during the transition to adulthood. Journal of Zoology 269:422433.

Hannon, S. J., K. Martin, AND J. A. Schieck. 1988. Timing of reproduction in two populations of Willow Ptarmigan in northern Canada. Auk 105:330-338.

HANNON, S. J., AND K. MARTIN. 1992. Monogamy in Willow Ptarmigan: Is male vigilance important for reproductive success and survival of females? Animal Behavior 42:747-757.

Hannon, S. J., P. K. Eason, and K. Martin. 1998. Willow Ptarmigan (Lagopus lagopus). Pages 1-28 in A. Poole and F. Gill (Eds.). The Birds of North America, no. 369. Academy of Natural Sciences, Philadelphia, and American Ornithologists' Union, Washington, DC, USA.

Hik, D., S. J. HANnON, AND K. Martin. 1986. Northern Harrier predation on Willow Ptarmigan. Wilson Bulletin 98:597-600. 
Holder, K., And R. Montgomerie. 2008. Rock Ptarmigan (Lagopus muta). In A. Poole (Ed.). The Birds of North America Online. Cornell Laboratory of Ornithology, Ithaca, New York, USA. Retrieved from The Birds of North America Online database: http://bna.birds.cornell.edu/bna/ species $/ 051$

IPCC. 2007. Climate change 2007. Synthesis Report. Contribution of the working groups I, II, and III to the Fourth Assessment Report of the Intergovernmental Panel on Climate Change. IPCC, Geneva, Switzerland.

JohnsGard, P. A. 1983. The Grouse of the World. University of Nebraska Press, Lincoln, Nebraska, USA.

KAler, R. S. A., AND B. K. SANDERCock. 2011. Effects of translocation on the behavior of island ptarmigan. Pages 295-306 in B. K. Sandercock, K. Martin, and G. Segelbacher (Eds.). Ecology, Conservation, and Management of Grouse. Studies in Avian Biology (no. 39). University of California Press, Berkeley, California, USA.

MACDONALD, S. D. 1970. The breeding behavior of the Rock Ptarmigan. Living Bird 9:195-238.

MARTIN, K. 1984. Reproductive defense priorities of male Willow Ptarmigan (Lagopus lagopus): Enhancing mate survival or extending paternity options? Behavioral Ecology and Sociobiology 16:57-63.

Martin, K. 1985. Herring Gulls prey upon female Willow Ptarmigan. Canadian Journal of Zoology 63:984-985.

MARTIN, K., AND F. CoOKe. 1987. Bi-parental care in Willow Ptarmigan - a luxury? Animal Behaviour 35:369-379.

Martin, K. 2001. Wildlife communities in alpine and subalpine habitats. Pages 239260 in D. H. Johnson and T. A. O'Neil (Eds.). Wildlife-Habitat Relationships in Oregon and Washington. Oregon University Press, Corvallis, Oregon, USA.

Martin, K., G. A. Brown, AND J. R. Young. 2004. The historic and current distribution of the Vancouver Island White-tailed
Ptarmigan (Lagopus leucurus saxatilis). Journal of Field Ornithology 75:239-256.

Martin, K., AND S. J. HANNON. 1987. Natal philopatry and recruitment of Willow Ptarmigan in north central and northwestern Canada. Oecologia 71:518-524.

Martin, K., S. J. Hannon, ANd R. F. RockWELL. 1989. Clutch size variation and patterns of attrition in fecundity of Willow Ptarmigan. Ecology 70:1788-1799.

Martin, K., And K. L. Wiebe. 2004. Coping mechanisms of alpine and arctic breeding birds: Extreme weather and limitations to reproductive resilience. Integrative and Comparative Biology 44:177-185.

Martin, K., P. B. Stacey, and C. E. Braun. 2000. Recruitment, dispersal, and demographic rescue in spatially-structured White-tailed Ptarmigan populations. Condor 102: 503-516.

Martin, K., S. Wilson, and S. J. Hannon. 2011. Mechanisms underlying variation in renesting ability in Willow Ptarmigan. Pages 233-246 in B. K. Sandercock, K. Martin, and G. Segelbacher (Eds.). Ecology, Conservation, and Management of Grouse. Studies in Avian Biology (no. 39). University of California Press, Berkeley, California, USA.

MERCER, W. E. 1967. Ecology of an island population of Newfoundland Willow Ptarmigan. Technical Bulletin no. 2. Newfoundland and Labrador Wildlife Service, St. John's, Newfoundland, Canada.

Mossop, D. H. 2011. Long-term studies of Willow Ptarmigan and Gyrfalcon in the Yukon Territory: A collapsing 10-year cycle and its apparent effect on the top predator. In R. T. Watson, T. J. Cade, M. Fuller, G. Hunt, and E. Potapov (Eds.). Gyrfalcons and Ptarmigan in a Changing World. The Peregrine Fund, Boise, Idaho, USA. http://dx.doi.org/10.4080/gpcw.2011.0206

Novoa, C., J.-F. Desmet, J.-F. Brenot, B. Muffat-Joly, M. Arvin-Berod, J. Resseguier, And B. Tran. 2011. Demographic traits of two alpine populations of Rock Ptarmigan. Pages 267-280 in B. K. 
Sandercock, K. Martin, and G. Segelbacher (Eds.). Ecology, Conservation, and Management of Grouse. Studies in Avian Biology (no. 39). University of California Press, Berkeley, California, USA.

Oyler-McCance, S. J., C. A. Stricker, J. St. John, C. E. Braun, G. T. WANn, M. S. O'Donnell, ANd C. L. Aldridge. 2011. Effects of climate change on nutritition and genetics of White-tailed Ptarmigan. Pages 283-294 in B. K. Sandercock, K. Martin, and G. Segelbacher (Eds.). Ecology, Conservation, and Management of Grouse. Studies in Avian Biology (no. 39). University of California Press, Berkeley, California, USA.

Peters, H., And T. D. Burleigh. 1951. The Birds of Newfoundland. Newfoundland Department of Natural Resources, St. John's, Newfoundland, Canada.

SANDERCOCK, B. K. 2006. Estimation of demographic parameters from live encounter data: A summary review. Journal of Wildlife Management 70:1504-1520.

SANDERCock, B. K., K. Martin, AND S. J. HANNON. 2005a. Life history variation in extreme environments: Comparative demography of arctic and alpine ptarmigan. Ecology 86:2176-2186.

SANDERCOCK, B. K., K. Martin, AND S. J. HANNON. 2005b. Demographic consequences of age structure in extreme environments: Population models for arctic and alpine ptarmigan. Oecologia 146:13-24.

SANDERCOCK, B. K., K. MARTIN, AND G. SEgelbacher. 2011. Ecology, Conservation, and Management of Grouse. Studies in Avian Biology (no. 39). University of California, Berkeley, California, USA.

SÆTher, B. E., AND Ø. BAKKe. 2000. Avian life-history variation and contribution of demographic traits to the population growth rate. Ecology 81:642-653.

Storch, I. 2000. Grouse status survey and Conservation Action Plan, 2000-2004. WPA/Birdlife and SSC Grouse Specialist Group, IUCN, Cambridge, UK.

StorCH, I. 2007. Conservation status of grouse worldwide: An update. Wildlife Biology 13:5-12.
WAng, G., N. T. Hobbs, H. Galbraith, AND K.M. Giesen. 2002a. Signatures of largescale and local climates on the demography of White-tailed Ptarmigan in Rocky Mountain National Park, Colorado, USA. International Journal of Biometeorology 46:197-201.

Wang, G., N. T. Hobbs, K. M. Giesen, H. GALBRAITH, D. S. OJIMA, AND C. E. BRAUN. 2002b. Relationships between climate and population dynamics of White-tailed Ptarmigan Lagopus leucurus in Rocky Mountain National Park, Colorado, USA. Climate Research 23:81-87.

WieBe, K. L., AND K. Martin. 1998. Costs and benefits of nest cover for ptarmigan: Changes within and among years. Animal Behaviour 56:1137-1144.

Wiebe, K. L., And K. Martin. 2000. The use of incubation behaviour by ptarmigan to adjust reproductive investment costs after egg laying. Behavioural Ecology and Sociobiology 48: 463-470.

WILSON, S. 2008. Influence of environmental variation on habitat selection, life-history strategies and population dynamics of sympatric ptarmigan in the southern Yukon Territory. Ph.D. thesis, University of British Columbia, Vancouver, Canada.

Wilson, S., AND K. MARTIN. 2008. Breeding habitat selection of sympatric White-tailed, Rock, and Willow Ptarmigan in the southern Yukon Territory, Canada. Journal of Ornithology 149:629-637.

Wilson, S., AND K. Martin. 2010. Variable reproductive effort for two sympatric ptarmigan in response to spring weather conditions in a northern alpine ecosystem. Journal of Avian Biology 41:319-326.

WILSON, S., AND K. MARTIN. 2011. Life-history and demographic variation in an alpine specialist at the latitudinal extremes of the range. Population Ecology 53:459-471. http://dx.doi.org/10.1007/s10144-011-0261-x

Wilson, S., K. Martin, AND S. J. HANNON. 2007. Nest survival patterns in Willow Ptarmigan: Influence of time, nesting stage, and female characteristics. Condor 109:377-388. 